\title{
The Mexican Peso Crisis: Implications for International Finance
}

\section{Edwin M. Truman, Staff Director of the Board's Division of International Finance, prepared this article.}

On December 20, 1994, the government of Mexico announced the devaluation of its currency, surprising financial markets and precipitating the so-called Mexican peso crisis. The devaluation came after three years during which Mexico had followed an exchange rate policy of maintaining the peso within a well-defined band against the U.S. dollar. During 1994, this policy had come under pressure as the Mexican current account deficit rose to about $\$ 29$ billion (8 percent of Mexican gross domestic product), Mexico's international reserves declined about twothirds, and the government of Mexico issued more than $\$ 25$ billion of peso-denominated short-term debt whose face value was indexed to the U.S. dollar. The devaluation on December 20 failed to stabilize peso financial markets; two days later, the Mexican authorities were forced to allow the peso to float freely, and its external value plummeted. In response, monetary and fiscal policies were tightened significantly, and Mexico received an unprecedented package of external financial support from the International Monetary Fund, the Exchange Stabilization Fund of the U.S. Department of the Treasury, the Federal Reserve, the Bank of Canada, and the Bank for International Settlements.

While the Mexican peso crisis has raised legitimate questions about Mexican economic policies before and during the events of December 1994 and January 1995, its propagation through international financial markets has also pointed to broader questions about the international institutional and financial environment. This article considers the implications for international finance of the Mexican experience. It focuses on these implications from three distinct and somewhat stylized perspectives: the creditors and their markets, the countries receiving large capital inflows, and the functioning of the international financial system.

Note. An earlier version of this article was prepared for and presented at the Aspen Institute seminar "The Future of the World Economy" in August 1995.
This three-way perspective is somewhat arbitrary and, therefore, not entirely satisfactory. First, it is oversimplified, particularly to the extent that it identifies creditors with investors in industrial countries, recipients of capital inflows (net or gross) with developing countries, and the international financial system with the governments (and the central banks) of creditor countries and with the international financial institutions that are held responsible for its smooth operation. In today's liberalized financial markets, potential creditors include investors in developing countries, industrial countries are large-scale recipients of international capital flows, and authorities both in developing countries and in industrial countries have a stake in the efficient and effective functioning of the international financial system. Thus, the notion that it is either appropriate or desirable for developed countries to operate under one set of rules while developing countries operate under another is increasingly off the mark.

Second, the origins of the Mexican peso crisis can be traced, in part, to trends in the globalization of finance over the past decade, trends with respect to the technology of markets, the liberalization of financial systems, and diversification of investors' portfolios. Whether these factors or Mexico's economic policy decisions, or neither, were more important in determining what happened in Mexico in late 1994 and early 1995 does not need to be agreed upon for the sake of my argument. I stipulate merely that the behavior of financial markets during the Mexican crisis has more in common with their behavior during the European monetary crises of 1992 and 1993 and the bond market collapse in 1994 than many observers may be willing to contemplate or acknowledge. ${ }^{1}$ Moreover, the similarities between the economic policies contributing to the Mexican crisis and those

1. Chairman Alan Greenspan testified before the Congress on January 26, 1995, that "although the speed of transmission of positive economic events has been an important plus for the world in recent years, it is becoming increasingly obvious-and Mexico is the first major case-that significant mistakes in macroeconomic policy also reverberate around the world at a prodigious pace." Statement before the Committee on Foreign Relations, U.S. Senate, Federal Reserve Bulletin, vol. 81 (March 1995), p. 261. 
contributing to the European monetary crises attest that the former was not a unique or unidimensional event. $^{2}$

Third, establishing the lessons to be learned from the Mexican experience is complex, particularly as there is no consensus on the factors behind the crisis. The International Monetary Fund (IMF) has listed three major views regarding such factors-adverse domestic political and external economic shocks, an unsustainable external position, and domestic policy slippages - and has noted that these views are not mutually exclusive. ${ }^{3}$ Moreover, the IMF's list of explanations largely omits economic and financial trends and developments originating outside Mexico. In part because there is no consensus on the factors behind the Mexican crisis, there is no consensus about what should have been done or not done during the crisis. Therefore, the lessons one person draws from the crisis are likely to be quite different from those another person draws.

\section{THE CREDITORS AND THEIR MARKETS}

The summary overview of capital flows to developing countries shown in table 1 incorporates several trends that have emerged since the early 1970s. First is the decline in the role for official capital inflows. Although not shown separately, these inflows are included in the "other" category, and in recent years their importance in total capital inflows to developing countries in Asia and the Western Hemisphere has declined substantially. Regarding total net capital inflows to all developing countries, borrowing from official creditors declined from $\$ 20$ billion per year between 1987 and 1990 (60 percent of total net flows) to $\$ 16$ billion per year between 1991 and 1994 (11 percent of total net flows). ${ }^{4}$

2. These parallels are much too interesting, complex, and controversial to be explored extensively in this article, but they are important to an understanding of today's financial world.

3. International Monetary Fund, "Factors behind the Financial Crisis in Mexico," World Economic Outlook (May 1995), pp. 90-97.

4. These data are compiled on a different basis from that used for table 1 and among other things include "exceptional financing," which is important and comes from the official sector even for the more advanced developing countries. The comparable figures for developing countries in the Western Hemisphere are net borrowing from official creditors of $\$ 7.9$ billion per year from 1987 to 1990 and net repayments of $\$ 0.7$ billion per year from 1991 to 1994 . Finally, for twenty-two countries classified by the IMF as market borrowers, net inflows from official creditors were $\$ 2.6$ billion per year from 1987 to 1990 (14 percent of the total) and $\$ 3.2$ billion per year from 1991 to 1994 (3.6 percent of total) (IMF, World Economic Outlook, tables A33, A34, and A35).
Second is the apparent decline in the role of commercial banks. Net flows directly involving foreign commercial banks (also included in the "other" entries) were the principal source of capital inflows from 1973 to 1982 for developing countries in Asia and the Western Hemisphere. During the debt-crisis period of the 1980s, countries in the latter group

1. Average annual net capital flows to developing countries, selected periods, 1973-94

Billions of U.S. dollars

\begin{tabular}{|c|c|c|c|c|}
\hline Area & $1973-76$ & $1977-82$ & $1983-89$ & 1990-94 \\
\hline \multicolumn{5}{|l|}{ All developing countries } \\
\hline Total capital inflows ... & 14.8 & 30.5 & 8.8 & 104.8 \\
\hline Foreign direct investment & & & & \\
\hline plus portfolio investment .. & -1.8 & .7 & 19.8 & 82.7 \\
\hline Foreign direct investment . & 3.7 & 11.2 & 13.3 & 39.1 \\
\hline Portfolio investment ..... & -5.5 & -10.5 & 6.5 & 43.6 \\
\hline Other $^{1} \ldots \ldots \ldots \ldots \ldots$ & 16.6 & 29.8 & -11.0 & 22.2 \\
\hline \multicolumn{5}{|l|}{ In Asia } \\
\hline Total capital inflows ........ & 6.7 & 15.8 & 16.7 & 52.2 \\
\hline $\begin{array}{l}\text { Foreign direct investment } \\
\text { plus portfolio }\end{array}$ & & & & \\
\hline investment $\ldots \ldots \ldots$ & 1.4 & 3.3 & 6.6 & 35.8 \\
\hline Foreign direct & & & & \\
\hline investment & 1.3 & 2.7 & 5.2 & 23.4 \\
\hline Portfolio investment & .1 & .6 & 1.4 & 12.4 \\
\hline Other $^{1} \ldots \ldots \ldots \ldots \ldots$ & 5.3 & 12.5 & 10.1 & 16.3 \\
\hline \multicolumn{5}{|l|}{ In Western Hemisphere } \\
\hline Total capital inflows ....... & 13.0 & 26.3 & -16.6 & 40.0 \\
\hline $\begin{array}{l}\text { Foreign direct investment } \\
\text { plus portfolio }\end{array}$ & & & & \\
\hline investment ........ & 2.4 & 6.9 & 3.2 & 38.5 \\
\hline Foreign direct & & & & \\
\hline investment & 2.2 & 5.3 & 4.4 & 11.9 \\
\hline Portfolio investment & .2 & 1.6 & -1.2 & 26.6 \\
\hline Other $^{1} \ldots \ldots \ldots \ldots$ & 10.6 & 19.4 & -19.8 & 1.5 \\
\hline \multicolumn{5}{|l|}{ Other developing countries } \\
\hline Total capital inflows ......... & -4.9 & -11.6 & 8.7 & 12.7 \\
\hline $\begin{array}{l}\text { Foreign direct investment } \\
\text { plus portfolio }\end{array}$ & & & & \\
\hline investment ........ & -5.6 & -9.5 & 10.0 & 8.3 \\
\hline Foreign direct & & & & \\
\hline investment & .2 & 3.2 & 3.7 & 3.8 \\
\hline Portfolio investment & -5.8 & -12.7 & 6.3 & 4.6 \\
\hline Other $^{1} \ldots \ldots \ldots \ldots$ & .7 & -2.1 & -1.3 & 4.3 \\
\hline \multicolumn{5}{|l|}{ Mexico } \\
\hline Total capital inflows & n.a. & 9.7 & -2.1 & 21.2 \\
\hline $\begin{array}{l}\text { Foreign direct investment } \\
\text { plus portfolio }\end{array}$ & & & & \\
\hline investment & n.a. & 2.3 & .1 & 18.7 \\
\hline Foreign direct investment & n.a. & 1.6 & 1.2 & 4.9 \\
\hline Portfolio investment ..... & n.a. & .7 & -1.1 & 13.8 \\
\hline Other $^{1} \ldots \ldots \ldots \ldots \ldots \ldots$ & n.a. & 7.4 & -2.2 & 2.5 \\
\hline
\end{tabular}

Note. Flows exclude exceptional financing from the International Monetary Fund or International Bank for Reconstruction and Development as well as bilateral official or private-sector reschedulings or arrears.

A number of countries do not report assets and liabilities separately. For these countries, it is assumed that there are no outflows, so that liabilities are set equal to the net value. To the extent that this assumption is not valid, the data underestimate the gross value.

Adjustments are also made to net out the effects of bonds exchanged for commercial bank loans in debt and debt service reduction operations and to provide additional detail on selected private capital flows.

Regional classifications correspond to those in the International Monetary Fund's International Finance Statistics but exclude capital exporting countries such as Kuwait and Saudi Arabia; "other developing countries" are those in the Africa regional grouping and the Middle East and Europe grouping. n.a. Not available.

1. Consists of net lending to the official sector (including general government and the monetary authority) and net lending to the private sector by banks and institutions such as insurance companies and pension funds.

Source. International Monetary Fund, World Economic Outlook database. 
experienced a reversal of such flows; and during the first half of the 1990s, bank flows played only a moderate role. These data, however, do not reveal the extent to which commercial and investment banks were involved in intermediating international capital flows. Although these institutions are heavily involved in the placement and arrangement of portfolio capital flows, the data include as banking flows only assets that are booked on the balance sheets of those financial institutions. For example, when the peso crisis erupted in December 1994, Mexican commercial banks had about $\$ 4$ billion in certificates of deposit outstanding to nonresidents; an overwhelming proportion of those deposits had been placed or brokered by foreign financial institutions.

Third is the absolute and relative rise in importance of net foreign direct investment. This trend reflects a widespread belief that this type of capital inflow has advantages in terms of both relative stability and the countercyclical nature of the associated servicing requirements; consequently, a more hospitable attitude in recipient countries toward such inflows has developed over the past decade or so.

Fourth is the dramatic increase in net portfolio investment. These flows take many forms, including investments in equity markets as well as investments in marketable debt instruments-denominated in domestic as well as in foreign currencies. In considering the implications of the recent Mexican experience, one must distinguish among these subcategories of portfolio investments because the investments involve a variety of risks-price risk, liquidity risk, and exchange rate risk. Broadly speaking, two types of investor are behind those flows: direct holders of the instruments in question and indirect holders through investment trusts or mutual funds. Whatever their type, investors seek to maximize their return given their appetite for risk. Unlike many direct investors, portfolio investors often have relatively near-term horizons - that is, the future that concerns them is a relatively brief period of timeregardless of the maturity of the underlying instruments. Unlike direct investors and traditional commercial bank lenders, they assume that they can liquidate their investments fairly quickly in welldeveloped trading markets. Moreover, near-term relative rates of return are important, as perhaps are considerations of capital gains and losses, for some instruments.

Fifth is the differing patterns of net capital flows across developing countries and groups of developing countries. The Asian countries have long received a larger proportion of their net inflows through foreign direct investment. The Western Hemisphere countries experienced a reversal of inflows from banks in the 1980s (embedded in "other" in table 1), and they were relatively large beneficiaries of net portfolio inflows during the first half of the 1990s.

Finally, the pattern of net flows to Mexico has been broadly the same as that for the group of Western Hemisphere developing countries. ${ }^{5}$

\section{The Unfolding of the Peso Crisis}

The lessons that observers draw from the Mexican experience for the creditors and their markets greatly depend on the perceived uniqueness of Mexico's circumstances. ${ }^{6}$ As we have seen, portfolio capital flows were important for Mexico, but they were also important to other countries in Latin America. In the Mexican case, however, the portfolio inflows were concentrated in instruments with relatively short maturities that were also readily transferable. Moreover, by the time the crisis hit, a large proportion of those instruments were tesobonos-short-term obligations of the Mexican government whose peso value was linked to the value of the dollar. At the end of 1993, foreigners also were very large holders of cetes-short-term government securities whose value was not linked to the dollar.

Indeed, one of the curiosities of the Mexican experience was that, over the course of 1994, international investors (Mexican as well as foreign) as a group sold cetes but willingly purchased tesobonos, instruments paying a much lower interest rate than that of cetes but a higher rate than that of similar U.S. government obligations. This trend continued even after mid1994, when it became clear that the outstanding stock of tesobonos was larger than Mexico's foreign exchange holdings. By definition, the return associated with cetes involved both an exchange rate and a credit (transfer) risk, whereas the return associated with tesobonos involved principally the latter; but both risks were substantial. ${ }^{7}$

5. In 1990-94, net portfolio investment was about two-thirds of net capital inflows to Mexico and the developing countries of the Western Hemisphere and was just under a quarter for developing countries in Asia.

6. The same qualification applies to the lessons for the recipients of capital inflows and for the international financial system.

7. For example, at the end of November 1994, the ninety-one-day cetes rate was 15.60 percent, a spread of 988 basis points over the U.S. three-month Treasury bill rate of 5.72 percent, whereas the ninety-oneday tesobono rate was 7.49, a spread of only 177 basis points. Technically, some exchange risk was originally associated with tesobonos because their principal was only indexed to the dollar; but the principal was paid in pesos, and the holder had to handle or cover the conversion of the pesos into dollars. 
Another observation about the Mexican situation may help to explain the relatively large ex ante gap between the rate on cetes and that on tesobonos: Since 1976, the international financial community, led by the U.S. authorities, had come to the financial assistance of Mexico on numerous occasions. The size and novelty of these operations may have suggested to investors that Mexico was a different, if not unique, sovereign borrower. An alternative explanation is that investors did not fully appreciate that tesobonos were a potential indirect claim on Mexico's international reserves.

Nevertheless, when the crisis broke, a large number of geographically dispersed investors were caught holding short-term claims on Mexico that could not be serviced without incurring a massive short-run depreciation of the peso. The investors realized that their investment strategies had been based on one or more false premises concerning the nature of Mexico's exchange rate regime or the probability that they could liquidate their holdings before any crisis hit. Also, although this explanation is difficult to prove, investors may have believed that "bondholders" would not be affected in a crisis because, even during the severe debt crises of the 1980s, there were only isolated instances of failures by countries to meet the original terms of this type of obligation. Finally, investors may have excessively embraced the socalled Washington consensus that the policy regimes in Mexico and similar countries had fundamentally changed in a direction that would produce sustained, rapid economic expansion. ${ }^{8}$

In actuality, holders of some types of portfolio claims on Mexico suffered losses in 1994-95, and holders of other claims did not. Holders of equity securities suffered losses, or at least paper losses. The Mexican stock market dropped two-thirds in dollar terms between December 19, 1994, and March 9, 1995, when it hit its low, and as of the end of January 1996 was still about one-third below its level before the peso's devaluation. The remaining foreign and domestic holders of cetes also suffered losses in dollar terms when their instruments matured over the course of 1995.

Holders of the tesobonos have not in the end suffered losses; the Mexican government has been able to honor its obligations, initially paying out pesos and meeting the resulting demand for dollars out of its reserves and later paying off foreign holders of tesobonos directly in dollars. However, on a

8. See Paul Krugman, "Dutch Tulips and Emerging Markets," Foreign Affairs, vol. 74 (July/August 1995), pp. 28-44. marked-to-market basis, holders of tesobonos suffered nontrivial, but temporary, paper losses as well as did holders of other, longer-dated Mexican debt instruments such as Brady bonds. ${ }^{9}$ Nevertheless, the widespread perception is that portfolio investors in Mexican paper suffered no losses as a consequence of the peso crisis and, on the whole, that they were well-rewarded for the limited risks taken.

When the crisis erupted, investors panicked, not only investors in the Mexican stock market and in Mexico's debt instruments but also investors in similar instruments issued by borrowers in other countries, especially countries in the same part of the world or perceived to be in similar circumstances. These contagion sales of assets were induced by at least two forces. First, as perceived risks rose and expected returns fell, individual investors wanted to disinvest. Second, institutional holders such as mutual funds, faced with actual or threatened redemptions, liquidated their holdings not only of Mexican paper but also of the paper of other countries, especially if they could do so while limiting their capital losses. These patterns can be seen in the sympathetic movements in the stripped yields on Brady bonds of various countries in Latin America and elsewhere (chart 1).

In the end, the wealth of Mexico's external creditors as a group was only marginally affected by losses following the crash of the peso. The principal reasons were that the investors were numerous and that Mexican paper was not a large portion of any final, nonMexican investor's total portfolio; a secondary reason was that some of the investors benefited from the actions taken to stave off a larger crisis. However, the Mexican situation was not unique. As long as no major institution or group of institutions is heavily invested in claims on such a country or a group of similarly situated countries, creditors and their markets are likely to suffer only limited damage. Consequently, they are unlikely to be motivated to act in concert with the issuer to limit losses on their investments; they have every incentive to step back from their investments and to dispose of them quickly, thereby adding to pressures in financial markets. On a global basis, portfolio investments in developing countries amounted to about $\$ 250$ billion as of the

9. Brady bonds are obligations of the Mexican government issued in 1990 in exchange for commercial bank claims. They were issued at an interest rate or principal amount reduced from that of the original obligations, and their principal and short-run interest payments are backed by collateral held at the Federal Reserve Bank of New York in the form of U.S. Treasury securities. They are called Brady bonds after former Secretary of the Treasury Nicholas Brady, who put forward the plan that led to their issuance. 
1. Secondary market yields on stripped Brady bonds of selected countries, Dec. 1994-Jan. 1996

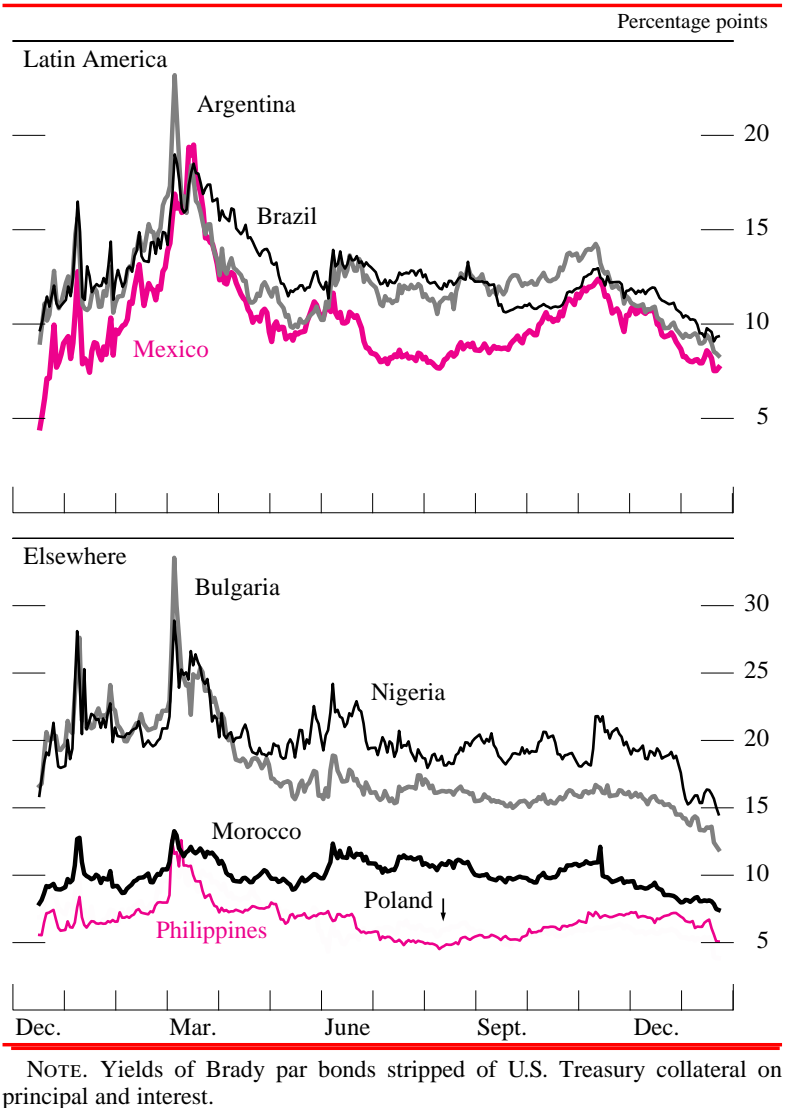
principal and interest.

end of 1994 (table 1). Although this number is large, it represents less than $1 / 2$ percent of total portfolio holdings of investors in industrial countries. ${ }^{10}$ Although investors would not have been happy losing, say, half the value of their investments in developing countries, even that result was likely to impose only small aggregate losses in terms of wealth, welfare, and demand. ${ }^{11}$

One circumstance is clear in Mexico's case and in that of many other countries as well: the lowered concentration and importance of commercial banks.

10. As of 1992, the total GDP of high-income countries was three times U.S. GDP; and as of year-end 1994, the financial wealth of U.S. households equaled \$18 trillion. If the wealth-GDP ratio for all high-income countries is the same as the U.S. ratio, financial wealth of households in high-income countries equaled about \$54 trillion when the peso crisis broke out (International Bank for Reconstruction and Development, World Development Report, Oxford University Press, 1994; and Federal Reserve, U.S. flow of funds accounts).

11. However, portfolio investments in these markets could become a larger share of global portfolios. Moreover, in terms of global growth, the indirect consequences of the hypothesized loss in value in early 1995 might have been substantial.
The situation in 1994-95 contrasts with that in the debt crisis of the early 1980s, when a small number of international commercial banks-roughly twentyfive in total-held a major share of Mexico's debt. In 1982, commercial banks accounted for 70 percent of Mexico's external debt, and claims on Mexico by the top nine U.S. commercial banks amounted to 50 percent of their capital. At the end of 1994, foreign commercial banks held less than 40 percent of Mexico's international debt, and claims on Mexico by the top nine U.S. commercial banks represented only 15 percent of their capital. Had Mexico defaulted this time, the consequences for those institutions would have been painful but not life-threatening.

\section{Implications for the Creditors}

The 1994-95 Mexican peso crisis is likely to be unique in at least one respect: In future liquidity crises, holders of large portfolio claims on the country facing the crisis are much less likely to avoid capital losses by relying on official actions that extend large-scale financial assistance to the country in question. The fundamental point is that the scale of potential financial assistance needed to stave off a full-blown crisis in Mexico has proved to be much larger than anyone could have imagined as recently as 1994, and the scale of any similar operation in the future (even allowing for the special circumstances of the Mexican case) is likely to be larger than the official sector will be able or willing to assemble. Moreover, as noted above, the widespread perception, whether accurate or not, is that many portfolio investors were inappropriately protected from the consequences of their investment decisions.

A further implication of the Mexican experience is that investors will be, or at least should be, more careful in the future. At a minimum, they should improve their early-warning systems. Many investors reportedly did not understand developments in Mexico in 1993-94; if they had, they would not have invested so heavily in tesobonos.

On the other hand, many of the investors, or at least their advisors, did in fact understand what was happening in Mexico in 1994; and either the managers of the investments ignored those developments, or they believed that they could divest before a full-blown crisis erupted. Just as in the European monetary crises of 1992 and 1993, many investors were mistaken. Thus, a third implication of the Mexican peso crisis is that institutions need to pay more attention to their risk-management systems in the broadest sense of that term. High or rising yields on 
debt instruments should serve as signals to their holders that compensation is being paid in advance for the costs of a possible default or capital loss.

Holders of portfolio claims on developing countries, as well as the financial institutions involved in placing the instruments (whether or not they continue to hold any in their own portfolios), should not expect that the next sovereign liquidity crisis will unfold in the same way the Mexican crisis did. Their planning should have two dimensions: They should expect to take more extensive losses, and, in part to improve the risk-reward trade-off, they may want to consider how they might participate responsibly in the ex post resolution of crisis situations should these situations occur.

\section{THE RECIPIENTS OF CAPITAL INFLOWS}

The changing pattern of international capital flows has both a supply side and a demand side. The previous section presented primarily the demand for a different mixture of investments than had been characteristic of the 1970s or 1980s; this section presents the supply side.

From the standpoint of the recipient countries, the 1990s opened up new opportunities to attract foreign capital. Those new opportunities were, in part, the consequence of changes in the political and social philosophies that governed the economic policies of the recipient countries. ${ }^{12}$ These countries became more hospitable to foreign direct investment by relaxing restrictions, rewriting discriminatory regulations, and reworking the landscape of the public sector through massive privatization programs that, in turn, caused portfolio investments in equity securities to become more attractive. The forces of economic reform led to more flexible economies, economies that in principle were better equipped to respond to shocks. However, the investments involved two-way risks, at least potentially, because the recipient countries to some extent became more exposed to the risk of a sharp change in investor sentiment. Funds that easily flowed in and financed current account deficits could also easily seek to flow out if conditions or perceptions changed.

The proposition about the increased risk to the recipient country is debatable, and it deserves closer scrutiny than it can receive here. However, an illustration may suffice. To induce foreign investors to hold

12. Some have argued that the "Washington consensus" on policies may have been overblown or overinterpreted in terms of its short-term implications for growth. claims on developing countries in the form of marketable debt instruments, the recipient countries had to compensate investors for the potential risks involved. Investors should have considered borrowers in developing countries to be similar to high-risk borrowers in domestic markets. By qualifying to borrow in these markets, borrowers in developing countries began to compete with a broader group of potential borrowers, not only in other developing countries but also in developed countries. Moreover, the competition was based on judgments concerning the adequacy of the returns considering the risks involvedevaluations that are relatively easy to make, at least in principle. But the comparisons are inherently multisided.

Thus, when yields declined on the bonds issued by industrial countries, yields on instruments issued by developing countries became relatively more attractive. (As discussed above, perhaps investors began to reach for higher yields without being as informed as they might have been about the risks involved.) Similarly, when yields in industrial countries rose in 1994, those offered by developing countries, such as Mexico, became relatively less attractive. The issue is whether, as a consequence of these structural changes, the borrowing countries have become more vulnerable to external financial shocks.

\section{Lessons for the Capital Recipients}

The principal lesson from the 1994-95 peso crisis for recipients of capital inflows derives from the size, scope, and speed of the crisis once it broke. By the standards of the 1980s, this was a new world.

The 1982 Mexican crisis took about six months to develop from the peso's devaluation in February to mid-August, when it became clear that the Mexican authorities would be unable to service their sovereign obligations. Not until December were mechanisms more or less fully in place to contain the situation. About $\$ 3 \frac{1}{2}$ billion in official bridge loans in August sufficed to buy time to establish more permanent solutions, but three months passed before an agreement with the IMF was completed to repay those loans. ${ }^{13}$

In 1994-95, the pre-crisis period lasted about a month, from mid-November to mid-December. An $\$ 18$ billion package of promised short-term financial

13. Bridge loans are short-term official credits extended with an assured source of repayment, usually from international financial institutions such as the IMF and World Bank. 
assistance was developed within two (holiday) weeks, but by mid-January it was clear that the classical, 1982 type of approach had failed to arrest the downward spiral of confidence. The U.S. Administration sought, and initially received, support from congressional leaders for a $\$ 40$ billion program of guarantees for Mexican government borrowings in international markets to refinance its short-term dollar and dollarlinked debt. That approach was abandoned on January 31 in favor of the approach now being followed. Thus, the crisis phase lasted a mere six weeks; after another six weeks, around mid-March, confidence began to return to Mexico (see chart 1). Of course, important differences between Mexico in 1982 and Mexico in 1995 make comparisons somewhat problematic. No one should doubt, however, that the 1982 approach quickly proved to be inadequate in 1994-95, whether or not it deserved that fate.

A second lesson from the Mexican experience is merely a variation on a familiar, long-standing theme: If a country is going to run a large current account deficit financed by net private capital inflows, it must ensure that the funds are being wisely invested. This is the first principle for any type of borrowing. In the international context, it is relatively easy to articulate but extremely difficult to apply. However, Mexico's current account deficit was clearly being driven partly by a decline in national savings from more than 18 percent of GDP in 1988-90 to less than 14 percent of GDP in 1994, and there was essentially no change in gross domestic investment. ${ }^{14}$ Thus, Mexico's domestic savings rate was relatively low, and when the Mexican economy increased its reliance on foreign savings, very little of the foreign money went to increased domestic investment. ${ }^{15}$

Three lessons of the Mexican experience pertain to other aspects of governmental policy. First, countries should not be tempted to try to sustain overvalued exchange rates too long; this principle is also easy to articulate but not so easy to apply. Second, and an easier lesson to apply, countries should avoid excessive reliance on short-term borrowing; because foreign as well as domestic investors buy internal as well as external debt, this lesson clearly applies to both areas of debt management. Third, when a country must devalue or otherwise change its exchangerate regime, it should make compensating and complementary changes in other macroeconomic

14. IMF, "Factors behind the Financial Crisis in Mexico," p. 92.

15. At least according to the aggregate statistics. Arguably, with the increased flexibility and openness of the Mexican economy, the actual investments were more efficient and productive in the 1990s than earlier. policies. In the Mexican case, these changes were not made immediately, either because the authorities were paralyzed by their governmental transition as President Zedillo succeeded President Salinas or because they did not understand the fundamental issue. Supporting the latter interpretation is the fact that the Mexicans did not request IMF support until the first week of January.

A final lesson from the Mexican experience is more of a question than a firm conclusion. Has the changing nature of international capital flows left recipient countries more vulnerable to shocks? On the negative side, one can argue that countries can more easily attract capital flows and that, because they are now more open and more flexible, they can more easily do without the capital inflows and adjust to their loss with less (not zero, but less) pain-at least as measured in terms of lost output. On the affirmative side, the unforgiving nature of capital markets may seem to imply that countries are more susceptible to severe punishment (in terms, again, of lost output) for small policy errors, although this increased market discipline may contribute to more responsible policies. ${ }^{16}$ As a practical matter, whether borrowing countries are more vulnerable to shocks today or not, they are less likely to receive much cooperation from their creditors in helping to cope with a crisis once it has erupted because individual creditors are more numerous and dispersed and have less of a stake in the success or failure of efforts to resolve or contain a financial crisis.

\section{Policy Implications for Capital Recipients}

Regardless of where one comes down on the issue of whether capital-importing developing countries are more vulnerable to shocks in today's globalized capital markets, one implication for the recipients of large-scale net capital inflows is that the authorities in these countries will need to pay a good deal more attention than they have in the recent past to potential shocks, both external and internal. They will need to develop their own early warning systems, which should differ from, and be independent of, the early warning systems that investors or official international financial organizations use because the requirements and risks are inherently different.

\footnotetext{
16. This lesson involving today's global financial markets is far from unique to Mexico's situation. It is central to the evaluation of the European monetary crises of 1992 and 1993 and the behavior of bond markets in 1994. It is also subject to dispute.
} 
Strengthening the domestic banking system is key to shock-proofing the economies of the borrowing countries. Such shock-proofing is clearly needed, whether because (1) those banking systems lack the managerial or financial strength to exploit liberalized financial markets effectively, (2) national supervisory systems are underdeveloped, or (3) international capital flows exert discipline over macroeconomic policies (with consequent strains on banking systems). In the Mexican case, all three rationales were present. The newly privatized banks lacked strength and managerial experience, the effective maturity of their foreign currency liabilities was much less than that of their corresponding assets, the supervisory system was underdeveloped, and the weaknesses of the banking system contributed to the reluctance of the authorities to take the macroeconomic policy steps that would have been necessary to contain the peso crisis once a devaluation appeared inevitable.

A second set of implications relates to macroeconomic policies in the countries receiving capital inflows. Many advocates of the use of exchange rates as nominal anchors for expectations about economic policies have been forced by recent events to retreat somewhat from their advocacy; it would be unfortunate if the pendulum now swung to the other extreme of absolutely freely floating exchange rates. The search for a workable, happy medium must continue.

At the same time, recipient countries will need to rethink the way they calibrate their monetary policies, their debt management policies, and their fiscal policies. Fiscal policy has a role to play in striking the proper balance between savings and investmentthat is, with respect to judging and achieving a sustainable current account balance-not only in industrial-country recipients of net capital inflows like the United States but also in developing countries like Mexico. ${ }^{17}$

Faced with unwanted capital inflows, as Mexico was in 1992 and 1993, countries confront difficult choices. One choice is to tighten fiscal policy further, even if tightening involves running a substantial fiscal surplus. Another is to allow the real exchange rate to appreciate. A third choice is to sterilize capital inflows and build up reserves, an approach that often

17. William Cline points out in his retrospective look at the debt crises of the 1980s that the flaw in former British Chancellor of the Exchequer Nigel Lawson's dictum that current account deficits do not matter so long as they are accompanied by balanced budgets or surpluses applies equally to developing countries and developed countries, and he correctly diagnosed this flaw as applying to the Mexican case well before the crisis broke. William R. Cline, International Debt Reexamined (Washington: Institute for International Economics, 1995). has negative fiscal consequences, as interest receipts on external reserve holdings are less than interest payments on domestic obligations. A fourth possibility is resorting to controls on capital inflows. A fifth is some combination of the above.

The capital controls "solution" has attracted increased favorable attention in some quarters in the aftermath of the Mexican crisis. ${ }^{18}$ However, in many cases, only countries with sound macroeconomic policies and high domestic savings rates can afford to limit capital inflows, and even they pay a price by distorting intertemporal decisionmaking. Moreover, when these countries do restrict some kinds of inflows (for example, short-term borrowing), they are reluctant to restrict other kinds of flows (for example, into stock markets or in the form of trade credits). Once the possibility of allowing some forms of shortterm or portfolio capital inflows is opened up, the nature of any ensuing crisis is at most a matter of degree. Finally, the notion that capital controls are a good idea for developing countries but a bad idea for developed countries runs counter to the observation that at the margin these two groups of countries cannot and should not be distinguished. ${ }^{19}$

\section{THE FUNCTIONING OF THE INTERNATIONAL FINANCIAL SYSTEM}

The principal change in the functioning of the international financial system in recent years has been the diminished role of governments. This trend is evident not only in the privatization and market-opening reforms in the non-industrial world but also in the deregulation in the industrial world. The Ministry of Finance no longer has quite the unchallenged power and influence it once had in Japan, and financial markets have become increasingly deregulated in all industrial countries. ${ }^{20}$

18. For example, the 64th Annual Report, 1994-95 of the Bank for International Settlements said that "emerging economies should perhaps be ... more prudent in dismantling controls on short-term capital inflows" (p. 210).

19. Lawrence Summers, the Treasury Department's Under Secretary for International Affairs during the crisis, has expressed my bias with his characteristic zing: "It is clear that we would all rather live in countries in which capital is trying to get in, rather than in countries from which capital is trying to get out. That suggests that countries should be very cautious about imposing capital controls with the objective of discouraging capital inflows" (Lawrence H. Summers, Remarks at Symposium on Capital Flows, Jerusalem, Israel, April 3, 1995).

20. One does not need to go so far as to argue that central bankers are like the little Dutch boy with his finger in the dike against the onslaught of stateless money as Steven Solomon does in his book The Confidence Game (Simon and Schuster, 1995) to recognize that the international financial system has changed. 
This trend toward deregulation has been driven by some of the same forces that are behind the globalization of financial markets and financial flows: technological change and improvements in global communications. These forces have also facilitated the relative rise in the importance of securities markets and the relative decline in the role of depository institutions as direct financial intermediaries (that is, as institutions that book both assets and liabilities on their balance sheets).

No trend toward increased volatility has been observed in those markets for financial assets that have been freely functioning for extended periods of time-for example, the market for U.S. Treasury securities and spot markets among the major currencies. Recorded volatility has, however, increased in markets that previously were controlled; whereas in the earlier era prices were tightly controlled, so that sharp movements were ruled out or transactions were never consummated, now prices are allowed to respond to shocks.

As noted above, the authorities have responded to these developments with a mixture of fear and awe. At one extreme, their concern about the scale of potential disturbances sometimes appears to handcuff them in their efforts to implement appropriate macroeconomic policies. At the other extreme, they have sought to exploit new opportunities, including new ways of raising money. Could the Brady bond market have developed without the debt crisis of the 1980s and without the financial technology to support it? Without this market to provide valuation benchmarks for trading in securities of developing countries, would it have been as easy for borrowers to price and come to market with other securities? These are difficult questions on which to reach firm conclusions. However, my answer to both questions is negative.

\section{Lessons for the Financial Authorities}

The principal lesson from the Mexican experience for the functioning of the international financial system is that the authorities must now rethink how they interact with the market in crisis situations. As noted earlier, gone are the days when the G-10 central banks could quickly assemble a bridge loan that would serve to stabilize expectations about the situation in a major borrowing country. Also gone are the days when the Managing Director of the IMF and the Chairman of the Board of Governors of the Federal Reserve System could gather representatives of the major private international financial institutions in a room and easily convince them that a systemic crisis is, first and foremost, a crisis for their own institutions. The number of important players is now much larger, and each perceives that it has less of a stake in the successful resolution of a crisis situation. Thus, when the Mexican authorities in December 1994 called upon the commercial banks to assemble a line of credit to help Mexico cope with what appeared to be a liquidity crisis, the commercial bankers' principal focus was on the terms of the deal rather than on the rationale for the deal. Whether this judgment was short-sighted or mistaken is open to debate.

A closely related lesson concerns the lack of consensus in the official community about the nature of the Mexican crisis and whether it involved so-called systemic risk. From a broad perspective, the situation contained four possible elements of systemic risk.

First was the risk to banking systems in countries other than Mexico; this narrow definition of systemic risk focuses on depository institutions that are the core of monetary and payment systems and that have access to governmental safety nets for depository institutions. Although bank claims on Mexico were a smaller share of Mexico's debt in early 1995 than in 1982, a full-blown Mexican crisis, which could have affected a number of other major borrowing countries, could have been a real threat to at least some national banking systems. ${ }^{21}$

Second was the risk to the broader international financial system, covering not only depository institutions but other types of financial institutions and extending to stock and bond markets around the globe. As argued previously, the loss of financial wealth as a consequence of contagion from the Mexican crisis was not likely to have been large enough by itself to have had a major impact on wealth, welfare, or demand in the industrial countries; but such adverse financial or psychological effects could not be ruled out.

Third was the risk to economic activity around the world, the possibility not only that the Mexican economy might go into a deep and prolonged recession with negative spillover effects but also that the Mexican crisis might spread to other borrowers and impart a global deflationary impetus of considerable size. From the perspective of the end of December 1994, this risk was seen as neither very large nor very troublesome after the vigorous growth in most of the

21. According to data from the Bank for International Settlements, which are not fully comparable for the two dates, bank claims on developing countries that are not members of the Organization of Petroleum Exporting Countries rose from \$247 billion in December 1982 to $\$ 489$ billion in December 1994. 
industrial countries in 1994; against the early 1996 background of slowing growth in many industrial countries (several still with high unemployment rates) and deep fissures in the Japanese financial system, this risk might be evaluated differently.

Finally, there was the risk to the global trend toward market-oriented reforms that had swept the developing world over the previous decade, drawing into the mainstream not only other countries in Latin America and the economies in transition in East and Central Europe and the former Soviet Union but also countries such as China and India. What if the authorities in Mexico (a country seen at the forefront of this trend) concluded from their experience that they had chosen the wrong model and then reverted to a model emphasizing nonmarket solutions? What would be the reaction in other formerly like-minded countries? Whether this consideration is relevant under the heading of "systemic risk" is debatable, but the authorities in most major borrowing countries did sit down in January 1995 to consider the implications of the Mexican situation for their economic and financial strategies. ${ }^{22}$

The fundamental issue is not primarily that all these elements of systemic risk were present in the Mexican situation, although I think they were. The point is that in the Mexican case there was no consensus on the nature or size of the systemic risk involved, nor is there likely to be in future cases. Consequently, the lack of consensus in the official community, as well as in private financial markets, on what to do about the situation is not surprising. ${ }^{23}$

A final lesson from the Mexican experience concerns the issue of transparency and markets, because these affect the way the global financial system functions. In the absence of full and accurate information, markets tend to trade on the basis of false premises, and investors react violently when the truth or a new rumor surfaces. In retrospect, the Mexican authorities were clearly less than fully forthcoming about their economic and financial situation; they were more transparent than critics in the market have argued, but they were not as transparent as they might have been. For example, until early 1995, Mexico announced its international reserve position only three times a year or when otherwise convenient. A more understand-

22. Again, see Krugman for a contrarian view: the Mexican peso crisis marked a healthy "beginning of the deflation of the Washington consensus" ("Dutch Tulips and Emerging Markets," p. 31).

23. This lack of consensus was exacerbated by the apparent success, by mid-1995, of international efforts to stabilize Mexico's external financial situation. Some have argued that such success proves that the official response to the Mexican crisis was not necessary, while others have argued, incorrectly in my view, the reverse. able failing, given that financial authorities are often behind the curve in such matters, is that the Mexican authorities chose to prevent the development of forward or futures market contracts in pesos. Nevertheless, this policy was inconsistent with other elements of market-oriented reform in Mexico. Some observers would like to see financial sector reforms in countries like Mexico phased in more slowly. Others argue that in the Mexican case the absence of financial market facilities such as a forward or futures market to absorb pressures associated with the peso's devaluation was one (but only one) of the reasons that the peso crisis of 1994-95 was more virulent than the European monetary crisis of 1992.

\section{Policy Implications for the International Financial System}

The first implication of the Mexican experience for the international financial system is that effective collective action requires a broader consensus on the nature of systemic risks in these types of situations. An evaluation should take full account of the moral hazard implications-that is, feedback effects on decisions by borrowers, investors, and international financial institutions-of adopting too broad or explicit a definition of systemic risk. What were the stakes for the international financial system and the world economy as Mexico was forced to devalue the peso in December 1994? What were the potential systemic implications? The U.S. authorities did not see them the same way that the authorities in some of the other major countries did. ${ }^{24}$

The second implication is that efforts to understand the functioning of financial markets and to safeguard their integrity should not be confined to markets in the industrial countries. Here, again, the Mexican experience reveals the continuum extending from the most sophisticated trading in foreign exchange markets involving the major currencies to domestic financial markets in developing countries.

Third is the implication for preventive activities. How best can the international financial community (private-sector as well as public-sector, including the international financial institutions) increase the probability that situations like the Mexico crisis either will not arise or will not involve such massive shocks to the economy of the country directly involved or to

24. This is not a clean distinction because disagreements about the nature of the threat were mixed with disagreements about whose responsibility it was to meet the threat. 
the world economy and financial system? Among the elements of better prevention are increased transparency and provision of data to markets, and three types of early warning system-one for the recipient country, one for the market participants, and one for the official international financial organizations.

Fourth, assuming that prevention is only 90 percent of any cure (at best), what scope should there be for international rescue operations in such circumstances? Here the beginning of a consensus is in the communique that came out of the Halifax Summit of Heads of State and Government of the Group of Seven Countries in July 1995. ${ }^{25}$ Few object to the principle that multilateral financial support should be potentially available to deal with certain crisis situations. However, considerable differences of view exist about how to define those crisis situations, about whether it is realistic (in light of trends in international financial markets) to think that the multilateral institutions can mobilize enough financial resources to deal with the "next Mexico" or the "fifth Mexico" thereafter, and moreover, about how

\footnotetext{
25. From the Halifax communiqué:

If prevention fails, financial market distress requires that multilateral institutions and major economies be able to respond where appropriate in a quick and coordinated fashion. Financing mechanisms must operate on a scale and with the timeliness required to manage shocks effectively. In this context we urge the IMF to: establish a new standing procedure-"Emergency Financing Mechanism" - which would provide faster access to Fund arrangements with strong conditionality and larger up-front disbursements in crisis situations. To support this procedure, we ask: the G-10 and other countries with the capacity to support the system to develop financing arrangements with the objective of doubling as soon as possible the amount currently available under the GAB [General Arrangements to Borrow] to respond to financial emergencies.
}

to deal with these situations without distorting incentives with respect to decisions of the various players (the moral hazard issue).

A search for a better way to manage these crises might proceed on the assumption that all crises will not, and perhaps should not, be preventable. But the analysis might also assume that decisionmakers will perceive a need to manage a crisis so that it does minimal damage to the functioning of the international financial system and the world economy; in other words, the option of leaving the country to work out its problems with the market will not be attractive in most circumstances. Finally, the analysis might assume that external emergency resources may well be inadequate to handle all such situations.

Under these assumptions, the answer to the question of whether there should be a better way to handle these crises obviously is yes. But such an obvious answer to a complex question suggests the need to examine the stated assumptions. At the same time, more orderly workout arrangements to govern international debt crises should be examined. For example, would an officially sanctioned standstill procedure that potentially would govern all external financial relations of a country in a crisis situation be either feasible or desirable? ${ }^{26}$ Any prediction as to the results of such an examination is premature; however, they are more likely to be evolutionary than revolutionary.

26. The Halifax communiqué cautiously endorsed such an examination: "Recognizing the complex legal and other issues posed in debt crisis situations by the wide variety of sources of international finance involved, we would encourage further review by G-10 Ministers and Governors of other procedures that might also usefully be considered for their orderly resolution." 